\title{
Application of iron ore mud in powder form in portland cement presence
}

\section{Aplicação de lama de minério de ferro em forma de pó na presença de cimento portland}

P. B. ARISTIMUNHO a peterson_ba@hotmail.com

S. R. BERTOCINI b bertocini@nin.ufms.br

\begin{abstract}
Among the products generated in the processing of iron ore, the mud washing, in most cases, is stored in tailing dams without a commercial use. This study aimed to evaluate, at the technical point of view, the application of mud washing iron ore in Portland cement mortar. Specimens were molded with varied proportions of cement, sand and mud washing in powder and then submitted to physical and mechanic tests. The results showed that the replacement of sand by the mud washing (emphasis to $20 \%$ substitution) improved the mechanical performance of mortars. It evidences the technical feasibility of the material under study.
\end{abstract}

Keywords: mortar, waste, iron ore.

\section{Resumo}

Dentre os produtos gerados no beneficiamento do minério de ferro, a lama de lavagem, na maioria dos casos, é armazenada em barragens de rejeitos sem um aproveitamento comercial. O presente trabalho buscou avaliar, do ponto de vista técnico, a aplicação desse resíduo na forma de pó em argamassa de cimento Portland. Desta forma, foram moldados corpos-de-prova com variadas proporções de cimento, areia e pó de minério de ferro e, posteriormente, submetidos a ensaios físicos e mecânicos. Os resultados demonstraram que as substituições da areia pelo resíduo (destaque para a substituição de $20 \%$ ) melhoraram o desempenho mecânico das argamassas. Isso demonstra a viabilidade técnica do material em estudo.

Palavras-chave: argamassa, resíduo, minério de ferro.

Universidade Federal de Mato Grosso do Sul, Departamento de Hidráulica e Transportes, peterson_ba@hotmail.com, Cidade Universitária S/N Bairro Universitário, Campo Grande /MS, CEP 79070-900;

b Universidade Federal de Mato Grosso do Sul, Departamento de Estruturas e Construção Civil, bertocini@nin.ufms.br, Cidade Universitária S/N, Bairro Universitário, Campo Grande /MS, CEP 79070-900 


\section{Introduction}

\subsection{Consumption of iron ore and environment}

The Brazilian consumption of iron ore is concentrated in the pig iron and pellets production. Based on production data for 2007 (35,5 Mt of pig iron and 55,0 Mt of pellets) and average consumption rates provided by the companies (1,68 ton of iron ore/ton of pig iron and 1,08 ton of iron ore/ton of pellets), it is estimated that the Brazilian consumption of iron ore in 2007 was about $119,1 \mathrm{Mt}$ (59,6 $\mathrm{Mt}$ in the manufacture of pig iron and 59,4 Mt in the manufacture of pellets). Compared to 2006, the Brazilian consumption of iron ore increased by $9.2 \%$. Worldwide consumption of iron ore is about 1.6 billion tons (DNPM [1]). Forecasts of the Brazilian Mining Institute indicate that investments in this sector will continue to grow over the next 20 years. The industry has evolved greatly in the optimization of its production units in order to increase productivity and meet the quality requirements and corporate sustainability.

The use that man has made of natural resources was not always considering its features and capabilities of recovery. More recently he became concerned about environmental problems. The emergence of serious environmental problems, with consequences on the man himself, led him to seek a better understanding of natural phenomena and to understand that should act as part of the natural system (Mota [2]).

The environmental conservation represents for companies an undeniable responsibility. On the other hand, more and more the market requires from companies a clear and concrete environmental preservation and conservation performance, which is embodied for carrying out activities that pose a minimal environmental impact (Ribó [3]).

\subsection{Beneficiation of iron ore and waste generation}

The studied waste is from Urucum Mineração S.A. belonging to Grupo Vale, located in Urucum Hill in the municipality of Corumbá (MS) $32 \mathrm{~km}$ away from downtown.

According to Lima [4], in this place the method of extraction of eluvial ore that occurs at the top of the hill is open and it's accomplished through embankments with a maximum height of 10 meters, no need for this exploration explosives, because the ore is already broken down naturally.
Beneficiation process of iron ore consists of crushing, washing and sieving. Iron ore is crushed and sieved on vibrating screens, in wet process, which generate the products: granulated iron $(6,35 \mathrm{~mm} \leq$ $\varnothing \leq 38,10 \mathrm{~mm})$, small hematite $(6,35 \mathrm{~mm} \leq \varnothing \leq 9,52 \mathrm{~mm})$, sinter-feed $(\varnothing \leq 6,35 \mathrm{~mm})$ and mud.

The mud treatment system works as follows: effluent mud from the washing of iron ore is carried by gravity through the channels until a thickener, where the most solid and sediment is drained through pipes to the tailing ponds located at the foot of the hill and the most liquid returns to the washing process of iron ore by pumping.

The volume of water consumed in the process is approximately $60 \mathrm{~m}^{3} /$ hour, with $60 \%$ recycled and $40 \%$ released in tailing ponds. As the washing operation is continuous ( $24 \mathrm{~h} /$ day, 7 days/week), you get a daily volume of mud in the order of $576.00 \mathrm{~m}^{3}$. According to analysis of Urucum Mineração S.A., the mud is composed of approximately $40 \%$ solids and $60 \%$ water. In tailing ponds the water evaporates and/or is reused in the process and the solids settle, where you get, finally, a volume of solid material around $230.40 \mathrm{~m}^{3} /$ day.

Among the products generated in the processing of iron ore, mud from washing, in most cases, is stored in tailings dams without a commercial use because the technology to transform this waste in metallic iron is more expensive compared to other products.

An example of recovering iron from iron ore tailings is using the technique of magnetizing roasting followed by magnetic separation (Li et al. [5]). Also, Chinese researchers have developed a new cementitious material in which $30 \%$ of its raw material is composed of iron ore tailings, obtained through a process of great thermal activation (YI et al. [6]).

\subsection{Objective}

This study aims to evaluate the mechanical performance of the application of sludge of iron ore in powder form in Portland cement mortars and thus, find answers regarding the technical feasibility of this application and what the best mixture.

\section{Materials and experimental program}

Specimens were prepared with varying proportions of cement, sand and iron ore mud in powder and, subsequently, subjected

\section{Figure 1 - Ball mill (at left) and iron ore in powder form after drying and milling (at right)}
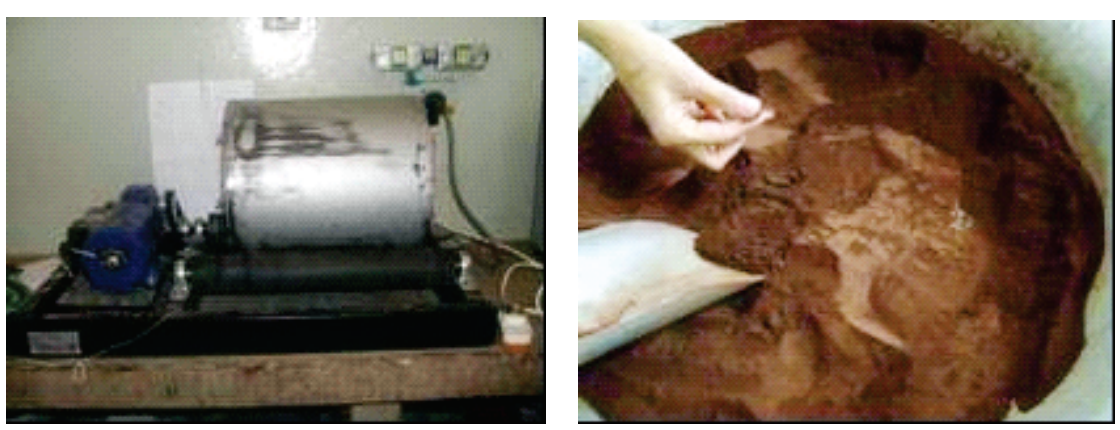


\section{Figure 2 - Molding of specimens (at left) and capping with mortar (at right)}
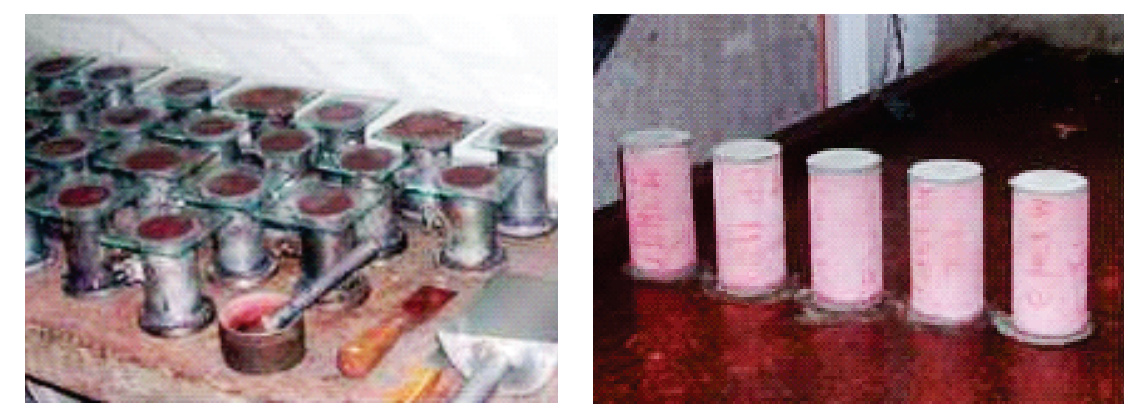

to physical and mechanical tests (determination of compressive strength, water absorption, void ratio, specific mass and consistency index - flow table).

Firstly, the mud was dried in the shade and homogenized by milling process in the ball mill (Figure 1). The grading curve of the residue after milling presented well graduated and characteristic of clayey silt. In addition, the material showed a value of density of solids equal to $3.79 \mathrm{~g} / \mathrm{cm}^{3}$, which is significantly high.

The natural sand of Campo Grande-MS was used as fine aggregate and Portland cement CPIIE32 (manufacturer Itaú) as a binder. The research design was at the Laboratory of Building Materials, Department of Structural and Construction, Federal University of Mato Grosso do Sul. Figure 2 shows the molding of the specimens and capping with mortar.

The compressive strength of the specimens prepared with different compositions of this study was determined according to ABNT NBR 7215 [7], the consistency index (flow table) according to ABNT NBR 13276 [8], the void ratio and specific mass according to ABNT NBR 9778 [9].

A reference mixture was adopted as a benchmark for all other mixtures of mortar. This reference mixture was prepared with mortar composed of one part of cement and three parts of sand and water/cement ratio of 0,60 .

To facilitate comparisons, the tests were divided in three groups according to their composition:
I) Additions;

II ) Sand Replacement;

III ) Cement Replacement.

Group I was prepared by making various additions of iron ore mud in powder in relation to the mass of cement in the reference mixture. There were additions of $4 \%, 6 \%, 8 \%$ and $20 \%$ ( $\%$ in mass). Group II was prepared by making various replacements of sand for iron ore in powder. There were sand replacements of $20 \%, 60 \%$ and $100 \%$ (\% in mass).

Group III was prepared by making various replacements of cement for iron ore in powder. There were cement replacements of $10 \%$, $20 \%$ and $30 \%$ ( $\%$ in mass).

\section{Results and discussions}

\subsection{Additions}

Table 1 presents the mean results of the compressive strength at ages 7, 28 and 90 days of the additions of $4 \%, 6 \%, 8 \%$ and $20 \%$ and the reference mixture, as well as their consistency indexes and water/cement ratio. In this group, the water/cement ratio was kept constant and it was observed that the consistency index tends to fall with the addition of powdered iron ore, except for the addition of $8 \%$. This anomalous behavior of the addition of $8 \%$ may be associated with a possible behavior of self-compacting of the powder.

Table 1 - Compression strenght, w/c ratio and consistency index of additions and the reference

\begin{tabular}{ccccccc|} 
Compositions & $\begin{array}{c}\text { Mixture in mass } \\
\text { cement: sand: IO } \\
\text { powder }\end{array}$ & $\begin{array}{c}\text { water/cement } \\
\text { ratio }\end{array}$ & \multicolumn{2}{c|}{$\begin{array}{c}\text { Results of compression strenght } \\
\text { in MPa }\end{array}$} & $\begin{array}{c}\text { Flow } \\
\text { Table } \\
(\mathbf{m m})\end{array}$ \\
Reference & $1: 3: 0$ & 0,60 & 16,14 & 24,55 & 24,36 & 243 \\
Addition 4\% & $1: 3: 0,04$ & 0,60 & 12,52 & 23,59 & 21,82 & 231 \\
Addition 6\% & $1: 3: 0,06$ & 0,60 & 18,75 & 30,69 & 30,00 & 231 \\
Addition 8\% & $1: 3: 0,08$ & 0,60 & 17,45 & 26,57 & 34,56 & 234 \\
Addition 20\% & $1: 3: 0,20$ & 0,60 & 12,03 & 21,75 & 20,60 & 212 \\
\hline OBS: IO=iron ore & & & & & & \\
\hline
\end{tabular}




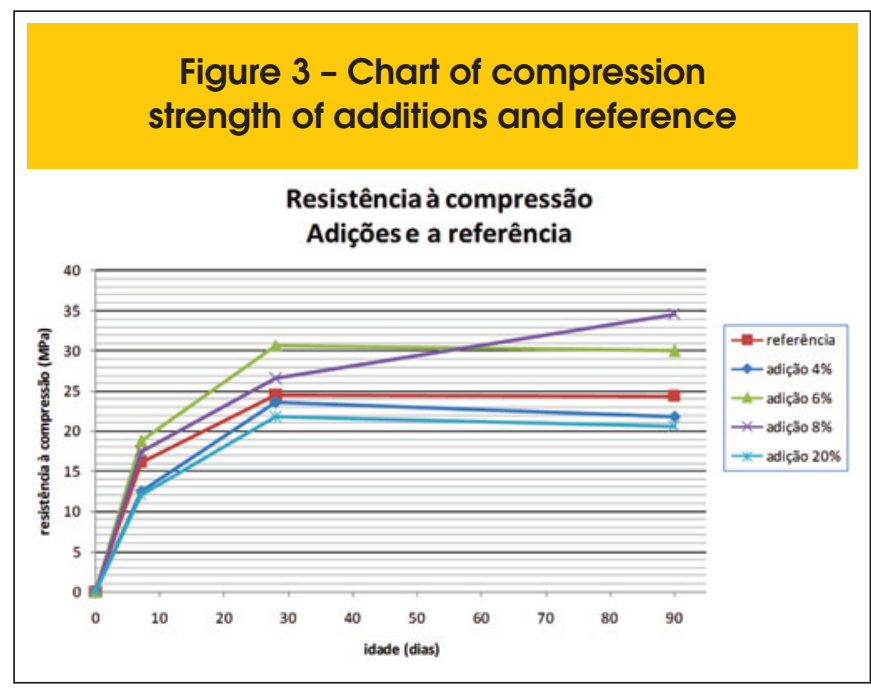

Figure 4 - Chart of compression strength of sand replacements and reference

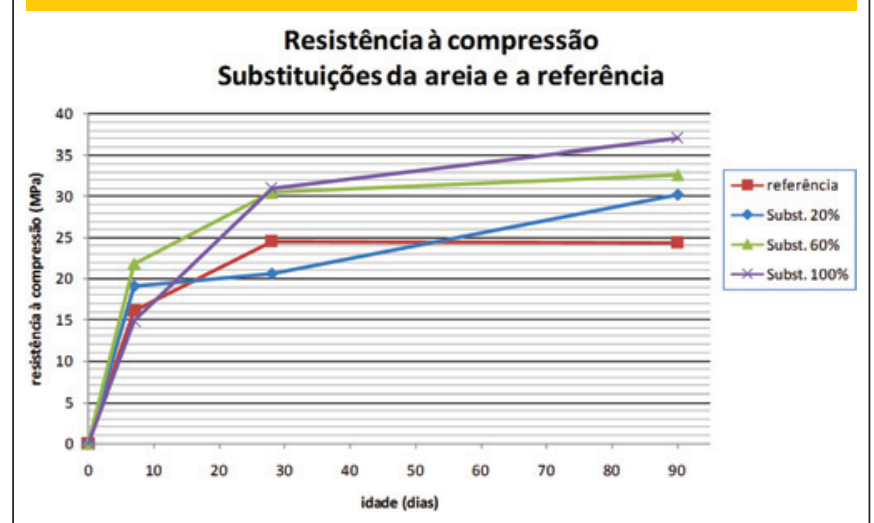

According to Figure 3 , the additions of $4 \%$ and $20 \%$ present lower resistances than the reference, while the additions of $6 \%$ and $8 \%$ have a higher resistance. Note that the resistance of addition of $6 \%$ tends to fall from the 50th day, but the resistance of addition of $8 \%$ tends to rise over time and reaches $35 \mathrm{MPa}$ at 90 days.

\section{Figure 5 - Chart of compressions strength of cement replacements and reference}

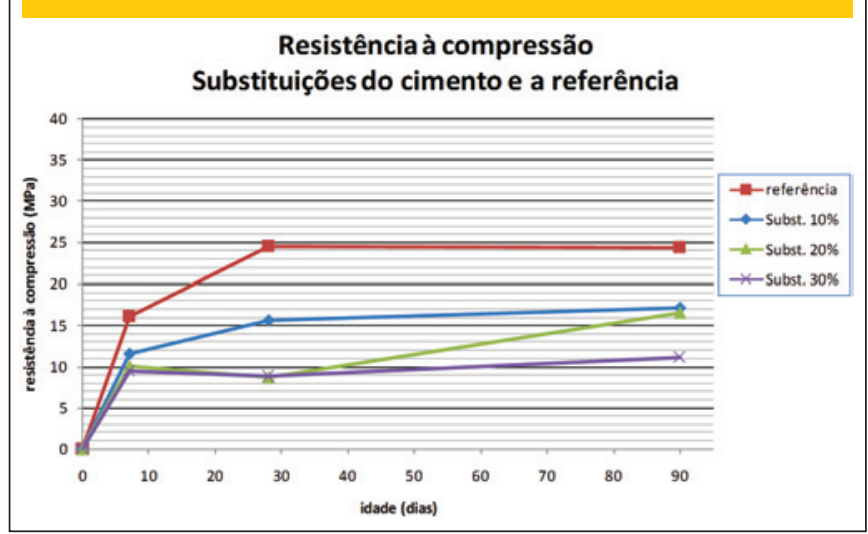

\subsection{Sand replacement}

Table 2 presents the mean results of the compressive strength at ages 7, 28 and 90 days of the sand replacements of $20 \%, 60 \%$ and $100 \%$ and reference, as well as their consistency indexes and water/cement ratio.

With the increased amount of powder, the workability of the mortar is damaged, requiring addition of mixing water. In the case of mortars with sand replacement was necessary to increase the water/ cement ratio in order to maintain an adequate workability. The lowest consistency index was observed in the sand replacement of $100 \%$, even with the highest water/cement ratio.

According to Figure 4, virtually all resistances are higher than the reference, especially the replacement of $100 \%$ reaching $37 \mathrm{MPa}$ at 90 days.

\subsection{Cement replacement}

Table 3 presents the average results of the compressive strength at ages 7,28 and 90 days of cement replacements of $10 \%, 20 \%$ and $30 \%$ and the reference, as well as their consistency indexes and water/cement ratio. It is observed that the consistency index and the water/cement ratio did not change significantly. According to Figure 5, all resistances are lower than the refer-

\section{Table 2 - Compression strenght, w/c ratio and consistency index of sand replacements and reference}

\begin{tabular}{|ccccccc|}
\hline Compositions & $\begin{array}{c}\text { Mixture in mass } \\
\text { cement: sand: IO } \\
\text { powder }\end{array}$ & $\begin{array}{c}\text { water/cement } \\
\text { ratio }\end{array}$ & \multicolumn{2}{c|}{$\begin{array}{c}\text { Results of compression strenght } \\
\text { in MPa }\end{array}$} & $\begin{array}{c}\text { Flow } \\
\text { Table }\end{array}$ \\
Reference & $1: 3: 0$ & 0,60 & 16,14 & 24,55 & 24,36 & 243 \\
(mm)
\end{tabular}




\section{Table 3 - Compression strenght, w/c ratio and consistency index of cement replacement and reference}

\begin{tabular}{|c|c|c|c|c|c|c|}
\hline \multirow[t]{2}{*}{ Compositions } & \multirow{2}{*}{$\begin{array}{l}\text { Mixture in mass } \\
\text { cement: sand: IO } \\
\text { powder }\end{array}$} & \multirow{2}{*}{$\begin{array}{l}\text { water/cement } \\
\text { ratio }\end{array}$} & \multicolumn{3}{|c|}{$\begin{array}{l}\text { Results of compression strenght } \\
\text { in } \mathrm{MPa}\end{array}$} & \multirow{2}{*}{$\begin{array}{l}\text { Flow } \\
\text { Table } \\
(\mathrm{mm})\end{array}$} \\
\hline & & & 7 days & 28 days & 90 days & \\
\hline Reference & $1: 3: 0$ & 0,60 & 16,14 & 24,55 & 24,36 & 243 \\
\hline Cement Replacement 10\% & $1: 3,3: 0,1$ & 0,60 & 11,56 & 15,66 & 17,15 & 243 \\
\hline Cement Replacement 20\% & $1: 3,75: 0,25$ & 0,60 & 10,1 & 8,75 & 16,51 & 242 \\
\hline Cement Replacement 30\% & $1: 4,3: 0,43$ & 0,60 & 9,46 & 8,79 & 11,16 & 241 \\
\hline OBS: $1 \mathrm{O}=$ iron ore & & & & & & \\
\hline
\end{tabular}
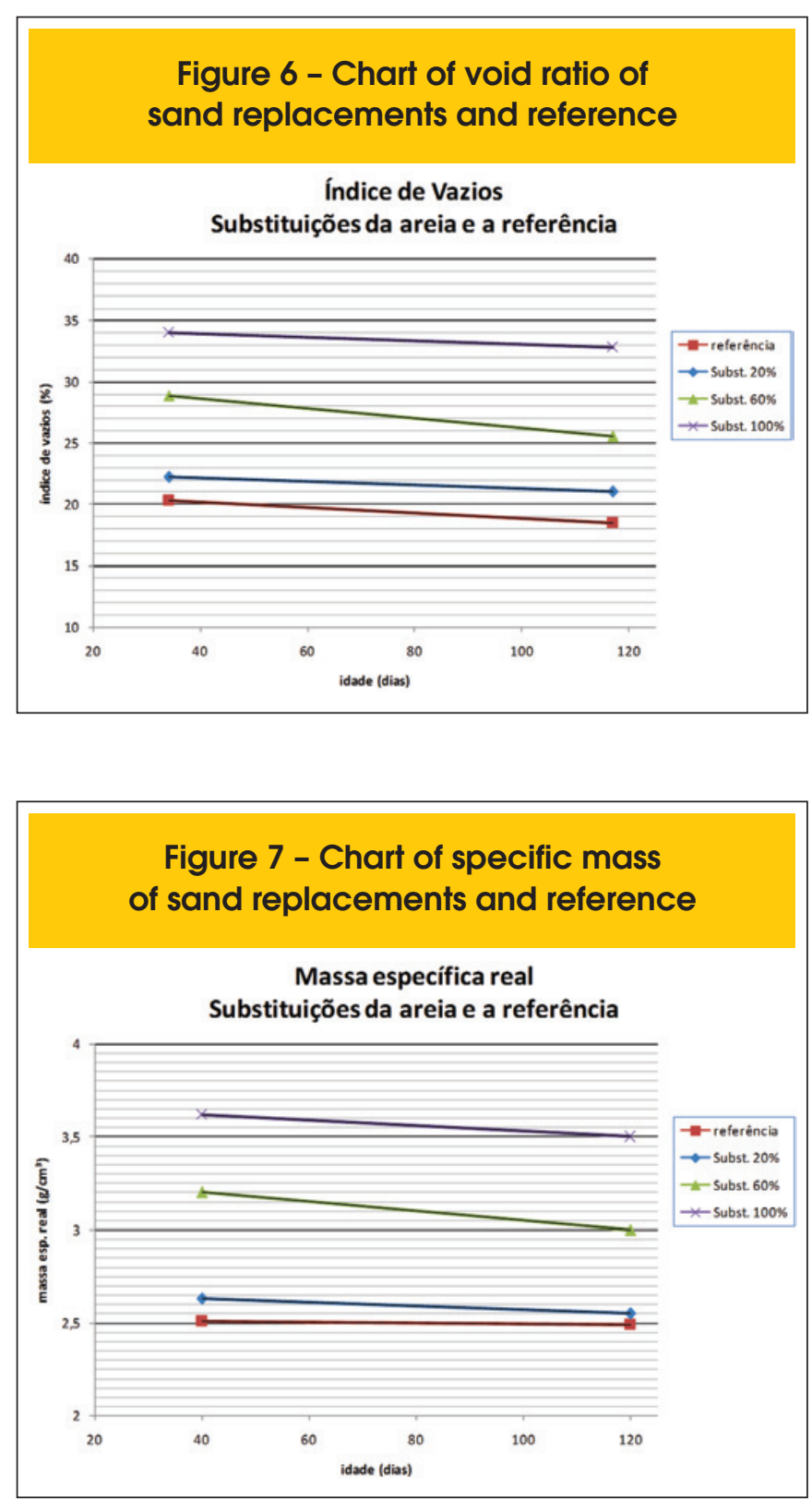

ence, and the $10 \%$ replacement of cement was less impaired and reached $17 \mathrm{MPa}$ at 90 days.

\subsection{Void ratio}

Void ratio (ratio between pore volume and the volume of solids) is directly proportional to the porosity of the material. Void ratio test was carried out only for the group of sand replacements and the reference, as shown in Figure 6.

It is observed that void ratio increases as the percentage of sand replaced by iron ore in powder increases. A larger amount of fine material affect the workability of the mortar and the compression of the layers. The mixtures were prepared applying the same energy of compression. An interesting suggestion is to apply higher energy of compression or use superplasticizer in sand replacements mixtures in order to reduce the void ratio. In general, when the void ratio decreases and, consequently, the porosity, the compressive strength is increased (Neville [10]).

\subsection{Specific mass}

The specific mass results were showed and discussed only for specimens with sand replacements, because this group presented the most significant values, while the others groups practically

\section{Figure 8 - Visual comparison of red color, reference and sand replacements}

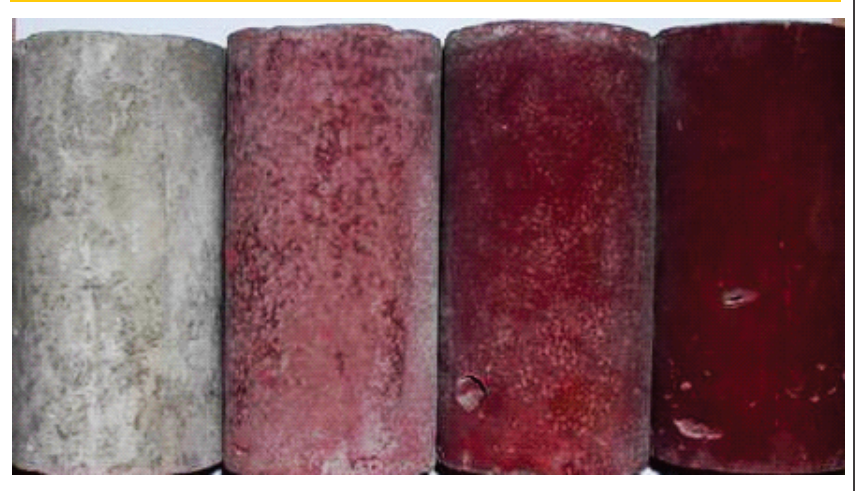


did not vary. Figure 7 shows the specific mass increases as the amount of sand replaced increases. Concrete with high values of specific mass can be harmful when used in beams and columns, longer recommended for floors and pavements.

\subsection{Visual appearance (color comparison)}

Note that a small amount of powdered iron ore is sufficient to confer reddish color and can get a very strong red as in the case of total replacement of sand (Figure 8). From the point of view of aesthetic, is an interesting feature because it "breaks" the gray color of the predominant materials based on Portland cement. In addition, this feature could mean a financial gain, since the use of synthetic chemicals for pigmentation raises the price of mortar and concrete artifacts.

\section{Conclusions}

\subsection{Technical aspects}

Among the additions of iron ore in powder, the addition of $8 \%$ showed the best result, because their resistances tend to increase at advanced ages and in all ages their resistances are higher than the reference. Moreover, the consistency index was not harmed and a smooth change of color (red) is realized.

Among the sand replacement, the replacement of $20 \%$ showed the best result, because their resistances are higher than the reference, the consistency index and its specific mass were not affected and showed good pigmentation.

On the other hand, the three replacements of cement had lower resistances to the reference.

It is concluded that the use of mud of iron ore in powder form in mortar is technically feasible, with better mechanical behavior when applied to the addition of $8 \%(1: 3: 0.08)$ and to replace $20 \%$ of the sand (1: $2.4: 0.6)$.

The replacement of sand in $60 \%$ and $100 \%$ had higher values of specific mass and, therefore, are recommended for floors and pavements. They also had a bad workability, but it can be corrected with the use of chemicals.

\subsection{Environmental aspects}

Whenever a sector of an industry recycles waste generated by another industry, it is said that there was an environmental gain in the production process of the two sectors because there is a lower demand for natural resources and energy. In this work, construction industries can reuse a waste generated by mining industries. It helps to establish a "closed loop" of energy and natural resources, which helps to minimize the environmental impact generated by these processes.

\subsection{Suggestions for future works}

- Study of practical application in cladding on walls using mortar with mixture $1: 3: 0.08$ (cement : sand : iron ore in powder);

- Study of applications in concrete replacing $20 \%$ of fine aggregate mass for iron ore in powder;

- Leaching tests;

- Economic feasibility study of the use of iron ore tailings.

\section{Acknowledgements}

The authors thank the Grupo Vale, CNPq and Federal University of Mato Grosso do Sul for the financial support and supply of materials.

\section{References}

[01] DEPARTAMENTO NACIONAL DE PRODUÇÃO MINERAL. Sumário Mineral Brasileiro. Brasília, 2008.

[02] MOTA, S. Introdução à Engenharia Ambiental. $4^{\mathrm{a}}$ ed, Rio de Janeiro: ABES, 2006.

[03] RIBÓ, J. Gerenciamento de Resíduos e Certificação Ambiental / [Coord.] FRANKENBERG, C. L. C.; RAYA-RODRIGUES, M. T.; CANTELLI, M. - Porto Alegre: EDIPUCRS, 2000.

[04] LIMA, J. F. Aproveitamento da Lama de Lavagem do Minério de Ferro: Estudo de Caso na Mineração Urucum - Corumbá/MS. Florianópolis, 2002. Dissertação de Mestrado - Programa de Pós-Graduação em Engenharia Civil - Universidade Federal de Santa Catarina

[05] LI, C. ; SUN, H. ; BAI, J. ; LI, L. Innovative methodology for comprehensive utilization of iron ore tailings: Part 1. The recovery of iron from iron ore tailings using magnetic separation after magnetizing roasting. Journal of Hazardous Materials, v. 174, n. 1-3, 2010; p.71-77.

[06] YI, Z. ; SUN, H. ; WEI, X. ; LI, C. Iron ore tailings used for the preparation of cementitious material by compound thermal activation. International Journal of Minerals, Metallurgy and Materials, v. 16, n. 3, 2009; p.355-358.

[07] ASSOCIAÇÃO BRASILEIRA DE NORMAS TÉCNICAS. Cimento Portland - Determinação da resistência à compressão. Rio de Janeiro, 1996.

[08] ASSOCIAÇÃO BRASILEIRA DE NORMAS TÉCNICAS. Argamassa para assentamento e revestimento de paredes e tetos - Preparo da mistura e determinação do índice de consistência. Rio de Janeiro, 2005.

[09] ASSOCIAÇÃO BRASILEIRA DE NORMAS TÉCNICAS. Argamassa e Concreto Endurecidos - Determinação da absorção de água, índice de vazios e massa específica. Rio de Janeiro, 2005.

[10] NEVILLE, A. M., Tradução GIAMMUSSO S. E. Propriedades do Concreto. São Paulo: PINI, 1997. 